\title{
TWO THEORIES OF VALUE IN MEDIEVAL ISLAM
}

Among the debates conducted in Islamic intellectual circles in the early ${ }^{\mathrm{C}} \mathrm{Abba}$ sid period, one of the most significant was the debate about the nature of value. To simplify the situation a little, we may say that two main theories opposed each other. One was that of the $\mathrm{Mu}^{c}$ tazila, that values such as justice and goodness have a real existence, independent of anyone's will, even God's : this view is classed as "objectivism." The other theory was that of Ash'ari and his like, that all values are determined by the will of God, who decides what shall be just and so forth: this will be called "theistic subjectivism." Following a struggle between the two doctrines, that of Ash'ari finally prevailed in most learned circles of medieval Sunnite Islam, a result which had far-reaching consequences in law and other spheres of Islamic civilization. As far as the writer is aware, no one has yet examined as a separate problem the reasons why the Ash'arite theory of value prevailed.

The primary philosophical question about value can be stated broadly thus : What is the common element in all that is called "good," "right," etc? This question includes the more specific ones of ethics: What constitutes a right action? and, How do we know the right action? At the outset the discussion will be carried on in terms of the broader question of value, because no less than this was made an issue among the Muslim theologians; at a later stage it will be appropriate to speak in terms of ethics. First of all it is necessary to go briefly over the meaning and history of the two broad theories that opposed each other.

By "objectivism" we mean any theory which affirms that value has a real existence in particular things or acts, regardless of the wishes or opinions of any judge or observer as such. (Objectivism is not necessarily absolutist; in fact most objectivist theories include a certain type of relativism. To take a material example, if we say that light clothing is better in a warm climate and thick clothing in a cold one, we are saying that each kind of clothing has a real objective advantage relative to a particular climate, and not merely a conventional acceptability or a subjective attractiveness to some people.) Objectivism in one form or another has been the prevailing view of western thought before the twentieth century. Socrates affirmed it when he convinced Euthyphro that piety is loved by the gods because it is good in itself; it is not made good by the mere fact that the gods love it. This was the view developed by Plato and Aristotle into the theory of the rational good, then upheld by the Stoics and most of the Catholic philosophers in the doctrine of natural right. In modern times Kant and other intuitionists, the utilitarians and some other naturalists, have all accepted the objectivity of value while differing about everything 
else. It may be termed the classical tradition of Europe, although there are exceptions. In Islam objectivism was upheld both by the philosophers, who were the full inheritors of the Greek tradition, and before them by the $\mathrm{Mu}^{\mathrm{c}}$ tazila, who came under some Greek influence. Most of the $\mathrm{Mu}^{\mathrm{c}}$ tazila asserted that there is a real good, which God wishes for the world, and a real justice which He upholds; and further that man can know what these are in specific instances by his reason.

The name "subjectivism" applies to any theory to the effect that the value of things or acts is always determined solely by the opinions or emotional attitudes of some judge or observer. In ancient Greece, many of the sophists put forward a social or conventional subjectivism: thus, what is called "justice" in a particular society is determined only by the opinions of the rulers, or of the majority. Similar types of theory have become fashionable in our age; they are "sophisticated" in a sense that is not always fully understood. In medieval Islam, however, subjectivism took a form which seems remote from the view of the sophists, though there is an underlying relation which was recognized by the acute mind of Ibn Rushd. 1 This was theistic subjectivism, the belief that "good," "right" and similar terms have no other meaning than "that which God wills": thus God makes things good or right for us by $\mathrm{His}$ decision that they should be so. It is denied that these words denote anything that has an objective existence; their meaning applies only to whatever God wishes, decrees or approves for the world. (This doctrine is also called "ethical voluntarism," but "theistic subjectivism" describes more closely the place of the theory in a logical classification of theories of value). This was the theory of value held by Ash'arī and all Ashcarites, including Ghazāli. It is not peculiar to Islam, since it occurs in medieval Judaism and occasionally in western thought; but it was probably more prominent and widespread in Islam than in any other civilization.

The prevalence of theistic subjectivism in Islam may appear surprising, if we judge it merely on its merits as a theory of value. Objectivism of one type or another may be thought more "natural" to man, in the sense that it has been more widespread in history and seems implied by most value language as it is used spontaneously and uninfluenced by theories. These matters cannot be argued here, but it is relevant to mention that in medieval Islam, too, objectivism was not without widespread support, both implicit in the practice of early Muslims and explicit in the writings of many distinguished theologians and philosophers. Some serious objections to theistic subjectivism were voiced, such as this consequence of it: that if God had commanded theft and idolatry, it would have been ipso facto right for

1 Jãmic $m \bar{a} b a^{\complement} d a l-t a b \bar{\imath} c a$, in Rasājil Ibn Rushd (Hyderabad, 1947), p. 172. After criticizing the Ashcarite theory of value he concludes: "All these are views like thase of Protagoras". Cf. Averroës' commentary on Plato's Republic, Heb. ed. and Eng. tr. E. I. J. Rosenthal (Cambridge, I956), I, xi, 3. 
man to commit them. Ash'arī, Ibn Hazm and Ghazāli did not shrink from accepting this extreme consequence; 2 but a philosopher like Ibn Rushd could well point out how such a position would undermine faith in God and belief in ordinary morality. ${ }^{3}$

When, on the other hand, we look at the two theories in the context of early Islamic thought, the triumph of Ash'ari's theory seems almost inevitable, given the way in which Islam was generally understood in those times. The rest of this article will be devoted to explaining why this was so, in medieval Sunnite Islam. Three kinds of reason may be found, which can be classified as ethical, theological and extraneous. The first will be dealt with at greatest length.

In dealing with the ethical reason we have to start from the history of Islamic jurisfrudence before the time of Ashcari. Here the Muslims faced a question of practical ethics which was more immediate than any philosophical question about ethics or value in general, namely: From what sources can a judge or mufti find out in all circumstances what is the right action? The starting points were, of course, the Qur ${ }^{\supset a}$ an and Traditions, and by the middle of the eighth century of the Christian era it was agreed that duties explicitly laid down in them were known from those sources. The question that remained, then, was how duties and right actions were to be determined when they were not mentioned in the Qur ${ }^{2}$ ān or Traditions. We may classify the answers into two main types, omitting many variations and details which need not concern us here.

I) On one side were lawyers who practised and allowed ijtihãd $a l-r a^{2} y$, the exercise of independent personal judgment in cases where the revealed sources did not contain explicit guidance. This was common practice in the ancient law schools of Madina and 'Irāq, which left their influence particularly on the classical schools of the two imãms Mălik and Abū Hanifa. "When it $\left(r a^{3} y\right)$ reflects the personal choice of the lawyer, guided by his idea of appropriateness, it is called istihsān or istihba $\bar{a} b$, preference.' The term istihsān therefore came to signify a breach of strict analogy for reasons of public interest, convenience or similar considerations." 4

The ethical basis which might justify such a practice may have remained unarticulated in the law schools; but $\mathrm{Mu}^{\mathrm{c}}$ tazilite theologians supplied a theory of ethics which could support $\ddot{i} t i h \bar{a} d a l-r a^{2} y$, if lawyers

${ }^{2}$ Ashcarī, Kitāb al-lumac, in The thcology of al-Ashcarī, ed. and Eng. tr. R. J. McCarthy (Beirut, I953), sect. I7I; Ibn Hazm, Kitāb al-fisal fil-milal, Leiden Warner MS. 480, Fol. 200a, quoted in I. Goldziher, Die Zähiriten (Leipzig, I884), pp. 163-64; Ghazālì, Al-iqtișād fill-ictiqudd (Cairo, Tijäriya Press, ist ed., n.d.), pp. $8 \mathrm{I}-82$.

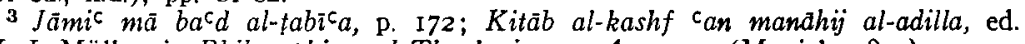
M. J. Müller, in Philosophie und Theologie von Averroes (Munich, 1859), p. I13.

$4 \mathrm{~J}$. Schacht, The origins of Muhammadan jurisprudence (Oxford, 1750). pp. $98-99$. 
wished to avail themselves of it. This was the theory that there is an objective good, including a real public interest and a real justice, and that these could be recognized by human reason, ${ }^{c} a q l$. The process of recognition involved can be termed "moral judgment," to distinguish it from other types of personal judgment. $R a^{3} y$, therefore, might have been restricted to moral judgment as described, and justified on that basis.

It might be supposed that all lawyers would have welcomed the latitude allowed them by a system in which judgments of public interest and equity would have been given an authorized position. But it appears that the attitude of legal theorists was in general dominated by fears that this latitude would be misused. Two dangers might be anticipated. One was that $r a^{3} y$ would be employed arbitrarily by caliphs, governors and other administrative officials exercising judicial powers. Very significant in this context is the rejection, in the early years of the 'Abbasids, of Ibn al-Muqaffac's theory that the caliph alone has the right to exercise $r a^{2} y$, and that he may use it to modify and codify Islamic law. 5 Acceptance of this proposition would have opened a valuable way to evolution of that law to cope with changing conditions. But from the lawyers' viewpoint Ibn al-Muqaffac was offering the worst of two worlds, for he was both withdrawing $r a^{2} y$ from themselves and allowing it to the chief executive. Thus they rejected it; probably they felt that a law based squarely on the Qurān and Traditions alone would serve a more vital purpose, by acting as a constitutional check on rulers and preserving Islamic standards in public life.

The other danger came from the side of Shicism. If $r a^{3} y$ were allowed, the opinions of ordinary lawyers were fallible. This would make more attractive the idea of a living authority, such as a Shicite imãm, who could give an infallible opinion. We know that much later, around I roo, Ghazāli was acutely aware of this possibility as a threat to the Sunnite community, and his answer rings out clear in refutations of the Bătinina: there is no need for a living imám; the imām of the Muslims is Muhammad, and all ethical and legal questions can be answered from the Qur ${ }^{3} \bar{a} n$ and Traditions. ${ }^{6}$ Now Ghazāli Shaficite, and his Shaficite ideas on law were perfect for answering

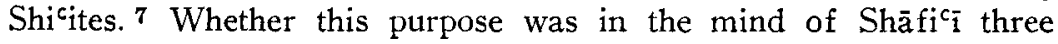

5 See S. D. Goitein, "A turning-point in the history of the Muslim state," Islamic Culture 23 (1949), pp. 120-35.

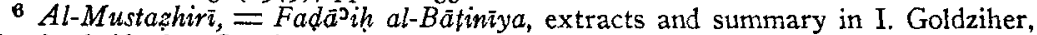
Streitschrift des Gazālī gegen die Bätinijja-Sekte (Leiden, 1916); Al-qistās almustaqim, in $A l$-jareāhin al-ghawāli (Cairo, 1934), p. I56 ff.; and especially $A l$ munqidh min al-daläl, ed. J. Salībā and K. cAyyãd, 3rd ed.' (Damascus, 1939), p. I I I ff.

7 The passage in Munqidh referred to in note 6 follows closely the arguments

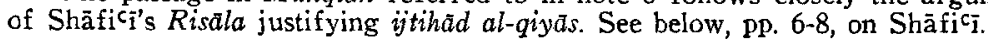


centuries before is another question, which could only be answered

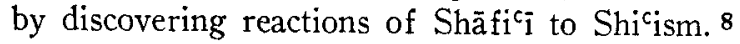

Quite apart from its lack of adoption by the legal profession, the

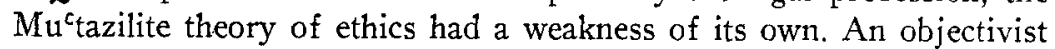
ethical philosophy ought to be able to show how moral judgment operates and to indicate the possibility of its being reasonable, if not scientific. But here the $\mathrm{Mu}^{\mathrm{c}}$ tazila failed, and their failure was almost inevitable at the stage in the history of religion and philosophy at which they lived. Aristotle had suggested that practical reason is directed by an end, the real good for man, but he had disappointingly not made clear what this right end is for a society, except for a few individuals who might find their fulfillment in the life of the intellect or the spirit. For Muslims, an end was indicated which applied to everyone, namely eternal happiness, al-sa $a^{\complement} \bar{d} d a t$ al-ukhräwiya. This suggests that the $\mathrm{Mu}^{\mathrm{c}}$ tazila might have developed a utilitarian type of ethics along the following lines: the end or interest (maslaha) of the Muslim community consists in the happiness of as many as possible in the next life; right action is that which promotes this end. But here they faced a theoretical gap between means and end which does not disturb a more worldly utilitarianism. It is possible to some extent to discover by empirical reason what produces happiness in an earthly society, and to see the causal relation between the means and the end. But where the goal is happiness in an after-life, given as a rezuard for a certain way of life on earth, the utilitarian formula throws no light on the practical means, the particulars of right conduct, for there is no intelligible relation between the cause (certain kinds of action) and the effect (the reward of bliss in the next life).

Moreover, even apart from its relation to the effect, the cause in itself could not be understood as having a single objective character. This was because the $\operatorname{shari}^{c} a$, or scripture regarded as a code of law, gave no unifying ethical principle to explain what is common to fasting, almsgiving, dealing just weight, etc., other than the fact of being commanded by God. Consequently a Muslim seeking guidance for an Islamic life on issues where the commands are not explicit or appear to conflict would find no rational method to follow, except the method

8 We can trace the opposition between Tradition and the call for an imān at least as far back as Khayyāt in the early tenth century. The following passage is worth quoting: "The doctrine that unbroken Tradition (al-khabar al-mutarcatir) is true and that it compels knowledge destroys most of the proof of the $R \bar{a} f i d a$ in affirming the imamate. That is because one of their chief proofs, in their own eyes, that people must have an infallible imām, pure within and withont, uniting all the sciences of religion, is that all the rest of the community besides him is liable to carelessness...": Kitāb al-intişār, ed. H. S. Nyberg and Fr. tr. A. N. Nader (Beirut, 1957), sect. Io3. Conversely, the Ismä cili $q \bar{a} d \bar{q} \mathrm{Nu}^{c}$ mān in the tenth century was denying the efficacy of qiyas because he knew that without it the Sunnite ("Traditional") theory of law would break down: $D a^{c} \bar{a}^{\top}$ im al-Islam, ed. A. A. A. Fyzee (Cairo, I95I), I, p. IO3 ff., quoted in B. Dodge, "The Fāțimid legal code", Mwslim World 50 (Jan. I960), pp. 30-38. 
of analogy with what is commanded, and this is exactly that qiya $\bar{s}$ which was recommended by the opponents of $r a^{3} y .{ }^{9}$

Lastly we may ask whether the sacred texts of Islam themselves gave any encouragement to an objectivist theory of value. This is a question which really requires a separate investigation; only a few general remarks may be made here. Certainly the Qur’ān often refers to values, such as al-ișläh, "doing good," which may easily be understood in an objective sense. It also urges man to think for himself, and such thought could be taken to include independent moral judgment. Then there are Traditions like the much-quoted answer of $M u c a \overline{d h}$ Ibn Jabal to the Prophet's question as to how he would decide cases in the absence of a text from God or the Prophet: "Then I shall use my own judgment (ajtahidu $r a^{3} y \bar{i}$ )." Unfortunately for the theory under discussion, no text gave unequivocal support to it; even

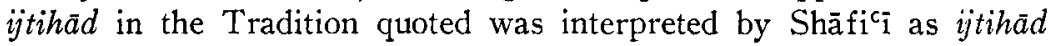
al-qiy $\bar{a}$, not involving independent moral opinion. 10 Meanwhile the quotations on the other side were more clear-cut, as will be shown.

2) The legal opponents of independent judgment were those who insisted that every decision must be justified by texts from the Qur aan or the Traditions or by the implications of such texts as determined by qiyās, "reasoning by analogy." On this side we must count the Shaficites and the Zãhirites: 11 these two groups differed on the legitimate methods, but they were at one on the fundamental principle of not allowing independent judgment. Now, corresponding to each weakness shown above in the position of the supporters of $r a^{3} y$, we find a point of strength on the side of the partisans of textual authority (nașs).

From the viewpoint of legal practice it looked like an advantage to be able to construct a complete positive law, which would provide for every judgment the solid authority of texts and their implications. The original Divine Law of the scriptures was like a regional map, with the roads well marked within the limits of the region. As jurisprudence is a science which aims to be precise and does not mind being slow, the ideal of most lawyers of medieval Islam was to construct a series of such maps, to cover the entire world of possible action.

In the field of ethical theory, the Shaficites and allied legal schools had a neat position: that right action could always be known from revelation or by legitimate extensions of it. Beyond that they did not

- Christian ethics follows a different course, because it is not a detailed set of laws but principles based primarily on the injunction to love God and to love one's neighbor, as expressed, for example, in Luke $10: 27$. These principles provide a method of judgment which can be applied in any moral situation. Thus analogies from the life of Christ do not have the same place in Christianity as qiyās in classical Islamic law.

10 Kitâb al-umm (Bulāq, I321-25 = I903-07), vii, p. 273.

11 The founder of the Zảhiriya, Dãwũd ibn Khalaf, was at first a Shaficite. His doctrine carried the main theoretical tendency of Shä fici to an extreme, by ruling out even qiyās as a source of legal knowledge. See Goldziher, Zähiriten, pp. $27 \mathrm{ff}$. 
need to go, though there are hints of a theory of value in some statements by Shā $\mathrm{fi}_{\bar{i}}{ }_{\bar{i}}$ and early theologians. 12

In the Qur'ān Shāfi $\bar{c}_{\overline{1}}$ found many quotations to support a theory of positive law: for instance, references to the Book as huda, guidance, and passages associating the guidance of the sunna of the Prophet with the judgments of the Book, or associating obedience to the Prophet with obedience to God. He attached key importance to the sentence, "Does man reckon that he shall be left to roam at random (yutraka sudan) ?", taking it to refer to man's moral situation. 13 But far more potent than explicit statements was the example of the Book's own practice. The Qur ān contains a number of injunctions that are clearly of legislative force and are stated as divine commands, prohibitions, permissions and so on. But these injunctions cover only a fraction of the spheres of conduct, whereas "al-Islam" means surrender of the human will to God's guidance in all spheres. Therefore, it was thought, God could not have left man without guidance in the remaining spheres-and this guidance can be expected to take the same form in principle as the explicit guidance of the Quranic legislation. This last step was fatally easy, especially in view of the failure of reason as a guide. In short, the prestige of the Qur'an led to the search for other positive sources to extend the scope of the $\operatorname{shari}^{-\mathrm{c}} a .{ }^{14}$

Having these advantages, the Shaficite principles prevailed in the classical theory of Islamic law which became consolidated in the course of the ninth century of the Christian era. The victory was qualified by one or two major concessions to opposing views; but it was none the less a victory, as we may see from the classical procedure of qiya $\bar{s}$ which is designed to exclude as far as possible any element of independent judgment.

Now we must notice that the Shaficite theory of scriptural authority as the basis for all legal and ethical knozvledge would naturally support a theory of value like theistic subjectivism, which claims that right and wrong have no meaning but the will of God. The theory of value is not quite a logical implication of the theory of knowledge, for it

12 Shāficī, Risala, ed. A. M. Shākir (Cairo, I940), p. 25: "Justice is obedience to God"; p. 33, quotes Qur'ān (Cairo) xxi, 23, "He shall not be questioned as to what He does". Ashcarí, Maqālāt al-Islämiyin, ed. H. Ritter (Istanbul, I929), p. IgI : Jacfar ibn Harb taught that God has willed that unbelief should be evil.

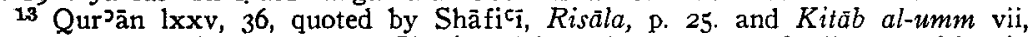
p. 27I. In the latter passage Shäfici claims the support of all authorities in understanding "sudan" as "what is neither commanded nor forbidden". This interpretation seems to read too much into the text, since the context concerns only the inevitability of the gathering of all men at the resurrection. More impressive is Qur'ān v, 41-50, with its refrain "So judge between them according to what God has sent down".

14 The same development took place in the history of Judaism, in which the oral law of the rabbis, and later the Talmud, grew up to supplement the limited commands of the Torah. We must not attribute the similarity directly to any inherited Semitic way of thinking; it is rather a seemingly logical outcome of the character of a Semitic scripture. 
is theoretically possible to hold that an objective right exists but that we can only know its practical applications through scripture. However, it is doubtful whether anyone held such a view. Certainly the Shaficites would be delighted to dispose of objective values, for this would cut the ground completely from under the feet of their adversaries, and leave the supposed "independent moral judgment" as nothing but idle fancy, as zann based on ahwera ${ }^{3}$. And since law and theology were so closely connected in the education of the ' $u l a m \bar{a}^{2}$, the prevalence of Shaficite ideas of law prepared the way thoroughly for the the later spread of the Ashcarite theory of value. It is not accidental that three of the greatest Ash ${ }^{c}$ arite theologians, Ash'ari, Juwayni and Ghazālī, were all Shaficites 15 and that Ibn Hazm was a Zāhirite.

The theological reasons for the triumph of Ash'arite subjectivism can be stated quite briefly. All of them are implications of God's omnipotence. The overwhelming power of God is greatly emphasized in the Qur`ān, so that it became the primary fact of religion for one broad school of thought, the self-styled ahl al-sunna who were the opponents of the $\mathrm{Mu}^{\mathrm{c}}$ tazila and the forerunners of Ashcarism. For them theistic subjectivism served three invaluable ends, and solved problems that might otherwise have arisen from the divine omnipotence.

I) Man seems powerful and clever when compared with the rest of visible creation. But the vast superiority of God can best be shown by contrast with man's real feebleness. As one aspect of the contrast, theologians of this school were disposed to stress, negatively that man is ignorant of any principles of ethics, and positively that God's will is the source that defines the right for man. Such doctrines would bring out man's utter dependence on God's help, through the $\operatorname{shari~}^{-} a$.

2) In relation to God, objective values appeared as a limiting factor to His power to do as $\mathrm{He}$ wills. The Muctazila discussed whether He could do evil if He chose. Naz̧āan said He could not, because justice is of the essence of His acts: this was logical for a $\mathrm{Mu}^{\mathrm{c}}$ tazilite, but it seemed to limit God's power. Others said God could do evil, but $\mathrm{He}$ would never do it, because of what $\mathrm{He}$ is--an answer which did not avoid contradiction, as Khayyāt pointed out. ${ }^{16}$ Ash'arī got rid of the whole embarrassing problem by denying the existence of objective values which might act as a standard for God's action. By defining "justice" as obedience to the commands of a law, he set God

${ }^{15}$ See Ibn eAsākir, Tabyinn kadhib al-muftarī, ed. H. Qudsī (Damascus, 1928-29), p. 140, Eng. tr. R. J. McCarthy, The theology of al-Ashcari, pp. 167-68: "The Shaficites followed the doctrine of al-Ash'ari and composed works agreeing with it."

16 Intisār, sect. Io: "When Ibn al-Rāwandī was asked, 'Do you deny that $\mathrm{He}$ actually does what you have described Him as capable of doing?', he answered, "That is impossible and absurd." 
free from the ethical limits that confine man, for "the Lord of the worlds ... is not under a shari $\bar{i}^{\mathrm{c}} a$." 17

3) The same answer conveniently solved the awkward problem of evil. There was an evident contradiction between the assertion that God is absolutely omnipotent, predestining man's good and evil acts and then punishing them for the evil ones, and the assertion that God is just in the sense we normally understand. Ash'ari and his school preferred to stand by omnipotence and throw out justice in the ordinary sense. This could be done if human justice were defined in ternts of law, since again "the Lord of the worlds ... is not under a $\operatorname{shari~}^{\mathrm{c}} a$ "- therefore "He is not foolish" when He wills folly in man. 18

Lastly, it is necessary to mention a chain of extraneous events having no particular connection with theories of value, namely the general defeat of the $\mathrm{Mu}^{\mathrm{C}}$ tazila in the ninth century. The main issue on which they met their downfall was the question of the creation of the Qur ${ }^{2} \bar{a}$. But their defeat on this point need not have involved a general decline if they themselves had not unwisely brought politics into theology a generation earlier. By accepting the official backing of the Caliph $\mathrm{Ma}^{\text {'mun }}$ and encouraging the persecution of their opponents as "unorthodox," they gambled with the risk of a reversal of the persecution, and this came to pass at the hands of Mutawakkil. Their opponents were too numerous and too steadfast, and, led by Ahmad Ibn Hanbal, they held out until the tide turned. The persecution of the $\mathrm{Mu}^{c}$ tazila in their turn was part of a conservative movement in Islam, perhaps a "failure of nerve," 19 led by the Caliph himself who was having trouble with his Turkish guards and tried to appeal beyond them to the broad support of the ahl al-sunna. Thus the check to $\mathrm{Mu}^{\mathrm{c}}$ tazilite ideas on value was to some extent just part of their misfortunes as a whole, but this did not reduce the seriousness of the consequences in the controversy about values. Henceforward any objections to their value theory would strike all the more sharply because they were now a minority sect under the disapproval of the 'Abbasid state.

In explaining within a limited space the dominance of one theory, this article has unavoidably been one-sided in dwelling more upon the weaknesses of one party and the strength of the other. It has been the writer's intention to show that the result was due to powerful forces in medieval Sunnite Islam, but not to show that it was a necessary product of Islam itself. For modern Muslims, what has been written has a certain relevance because they face essentially the same problem

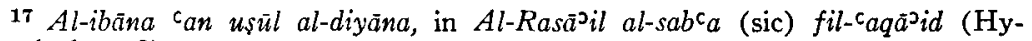
derabad, 1948), p. 54.

18 Ibid.

19 G. Murray, Five stoges of Greek religion (London, 1935), ch. 4 referring to later Greek religion.
} 
about value as their medieval predecessors. But the interest of the medieval solution lies less in any immediate acceptance that it may receive today than in its resemblances and contrasts with what Muslims of our time are likely to think. It is doubtful that many of them will return to a pure Ashcarite theory of value, but it is hoped that a detached study of the origins of that theory will assist some Muslims and some non-Muslims to clarify their thoughts on value in its relation to Islam.

University of Michigan

George F. Hourani

Ann Arbor, Michigan 